\title{
Development Of A Conceptual Framework Regarding The Factors Inhibiting Teachers' Successful Adoption And Implementation Of ICT In Teaching And Learning
}

\author{
Dr. Sujit Kumar Basak, Durban University of Technology, South Africa \\ Dr. Desmond Wesley Govender, University of KwaZulu-Natal, South Africa
}

\begin{abstract}
This paper presents a conceptual framework regarding the factors inhibiting teachers' successful adoption and implementation of ICT in teaching and learning, derived from an in-depth survey of the related literature. The aim of this study was achieved by identifying the factors that inhibit teachers' adoption and implementation of ICT in teaching and learning. The main result of this study is a framework, derived from the existing literature, of inhibiting factors regarding teachers' adoption and implementation of ICT in teaching and learning. The findings help to articulate issues related to teachers' adoption and implementation of ICT and in this way contributes to the development of programs designed to address the relevant issues.
\end{abstract}

Keywords: ICT Adoption; Teaching \& Learning; Teachers \& ICT; Factors \& ICT; ICT Framework

\section{INTRODUCTION}

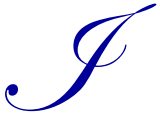
$\mathrm{n}$ the $21^{\text {st }}$ century, the rapid growth of Information and Communication Technology (ICT) has changed modern society (Tomei, 2005) and has dramatically reshaped teaching and learning in education (Pulkkinen, 2007; Wood, 1995). Increasing the quality of teaching and learning is essential for successful education. Since the beginning of the century education has faced social, cultural, economic and technical challenges (Januszewski \& Molenda, 2008). The impact of ICT plays a critical role in education (Webber, 2003) and provides a strong teaching and learning environment for students (Volman \& Van Eck, 2001; De Corte et al. 2003). ICT can be used to complement existing teaching methods to support the teaching and learning enterprise (Nyambane \& Nzuki, 2014). ICT is helpful for teachers' lesson preparation and delivery (Apawu, 2011; Wodi, 2008) and can improve student learning and motivation through addressing issues such as multiple intelligence levels and different learning styles (Schrand, 2008).

\section{PROBLEM STATEMENT}

According to Sharma (2003) and Republic of Uganda (2007), the cost of ICT training materials negatively affects ICT implementation in higher education at Kabale District in Uganda. Mumtaz (2000) reports that the limited resources of ICT for teachers in schools are a challenge for implementation of ICT. Similarly, Zziwa (2001) reports that in the French education system the high cost of computer materials is the main obstacle to the adoption of ICT in schools. A study conducted by Malcom and Godwyl (2008) concluded that in Ghanian secondary schools the fundamental problem is the high price of computers and the lack of infrastructure to implement ICT. Aryatuha (2007) stated that in Africa economies are very poor and for that reason resources to train staff are very limited. Priscilla et al. (2008) concluded from their study that the lack of technical skills and complexity of operating computers confused teachers and inhibited integration of ICT into their classrooms. Lim and Teo (1998) reported that teachers' main obstacle is the lack of technical and educational training. According to Hsin-Kai et al. (2007), teachers' technical skills are the critical issue for successful implementation of ICT in the classroom. 


\section{RESEARCH QUESTION}

- What are the important factors that inhibit teachers' successful adoption and implementation of ICT in teaching and learning?

\section{AIMS AND OBJECTIVES}

The aim of this study was to develop a conceptual framework regarding the factors inhibiting teachers' successful adoption and implementation of ICT in teaching and learning. This aim was achieved through accomplishing the following objectives: identifying the factors inhibiting teachers' implantation of ICT in teaching and learning; testing the relationship to each other of these factors.

\section{LITERATURE REVIEW}

ICT integration into teaching and learning is very complex and one can easily encounter a number of difficulties and these difficulties are popularly known as "barriers" (Schoepp, 2005). Stockdill and Moreshouse (1992) identified the variables that need to be assessed regarding successful adoption and integration of ICT as follows: user characteristics, technological considerations, content characteristics and organizational capacity. Balanskat et al. (2007) found that barriers for the successful implementation of ICT are found at teacher-level, school-level, and system-level. According to Sherry and Gibson (2002), barriers to implantation of ICT can be individual, technological, organizational, and/or institutional.

Pelgrum (2001) found that the lack of knowledge and skills, insufficient number of computers, lack of infrastructure and difficulty in integrating ICT based instruction in the classroom are the factors that negatively affect the implementation of ICT by teachers in education. A study by Martins et al. (2004) revealed that observability and trialability are the significant factors that affect the implementation of ICT. Studies conducted by Winnans and Brown (1992), Dupagne and Krendl (1992) and Hadley and Sheingold (1993) found that barriers to implementation of ICT are: lack of teaching experience with ICT; lack of on-site support for teachers using ICT; lack of help supervising children using computers; lack of ICT specialist teachers to teach students computer skills; lack of computer availability; lack of time required for successful integration of ICT into the curriculum; and lack of financial support. A report from Ghana indicated that limitations imposed by the inadequate number of the computers in institutions, poor trained educators, and the lack of internet connectivity are the major challenges to implementation of ICT in teaching and learning (Mereku et al. 2009).

Other barriers to integration of ICT into education programs include the following: lack of in-service training (Beggs, 2000; Mehlinger \& Powers, 2002; Schoep, 2004), lack of appropriate software/materials (Brush et al. 2003; Bullock, 2004; Mumtaz, 2000; Natz \& Lundgren, 1998; Williams et al, 1998), lack of basic knowledge/skills for ICTs (Brush et al. 2003; Mehlinger \& Powers, 2002; Mumtaz, 2000; Schoep, 2004; SchoolNetAfrica, 2004; Williams et al. 1998), lack of hardware (Beggs, 2000; Brush et al. 2003; Bullock, 2004; Mehlinger \& Powers, 2002; Mumtaz, 2000; Schoep, 2004; SchoolNetAfrica, 2004; Williams et al, 1998), lack of technical support (Brush et al. 2003; Bullock, 2004; Mehlinger \& Powers, 2002; Natz \& Lundgren, 1998; Schoep, 2004), lack of appropriate course content and instructional programs (Mehlinger \& Power, 2002; Schoep, 2004), lack of time (Beggs, 2000; Brush et al. 2003; Mumtaz, 2000; Schoep, 2004), lack of appropriate administrative support (Natz \& Lundgren, 1998; Schoep, 2004; SchoolNetAfrica, 2004).

Becta (2004) proposes that there are two levels of barriers affecting teachers' adoption and integration of ICT in teaching, namely, individual (teacher-level barriers) and institutional (school-level barriers). The teacherlevel barriers include lack of time, lack of confidence, and resistance to change and the school-level barriers include lack of effective training to solve the technical problem and lack of access to the resources. Snoeyink and Ertmer (2001) also propose two types of barriers that affect implementation of ICT in schools. The first order barrier includes lack of equipment, unreliability of the equipment, lack of technical support and other resource-related issues and the second order-barrier includes school level factors such as organizational culture, and teacher-level factors. Pelgrum (2001) names two kinds of obstacles to ICT adoption, namely, material and non-material. The 
material conditions include insufficient computers or software, and the non-material conditions include lack of teachers ICT knowledge and skills, difficulty of integrating ICT based instruction, and insufficient time for teachers.

A research result from Gomes (2005) shows that the science teachers are usually resistant to adopt new strategies so new strategies become obstacles to integration of ICT in science teaching. Özden (2007) and Toprakci (2006) found that in Turkey lack of in-service training programs for science teachers is the main problem preventing implementation of ICT in schools. Toprakci (2006) found that the limited number of computers, oldness or slowness of ICT systems and scarcity of educational software in schools are the main barriers that affect to implement of ICT in science education. Beggs (2000) found that one of the top three barriers to adoption of ICT is the lack of training for teachers. A study conducted in Saudi Arabia by Al-Alwani (2005) found that lack of time is the main barrier affecting teachers' implementation of ICT. Similarly, a study conducted in Canada by Sicilia (2005) showed that teachers take more time to prepare ICT based lessons compared to traditional methods.

Cox et al. (1999) study revealed that a lack of ICT resources in schools and insufficient time to review software prevents teachers from using ICT. Bisht (2013) found the following reasons for lack of implementation of ICT in schools: lack of access to technology, lack of ICT training and practice in teaching, lack of connection between personal uses of ICT students learning with the help of technology, lack of connection between personal uses of ICT to teaching students to learn with technology attitude towards computers, lack of self-confidence, lack of technical and instructional support, and finally the lack of mentor teachers. Research results from Afshari et al. (2009), Beggs (2000), Newhouse (1999), and Ihmeideh (2009) suggest that time is the biggest factor that negatively affects implementation of ICT in education. A study conducted in Europe by Empirica (2006) found that lack of access, lack of computers, lack of adequate materials and lack of skills are the biggest barrier to use ICT in teaching by teachers. Korte and Hüsing (2007: 4) found that in European schools infrastructure barriers such as broadband internet inhibits implementation of ICT by teachers.

A study conducted by Kessy et al. (2006) found that corruption is one of the main factors that affects implementation of ICT in education. Mamun and Tapan (2009) state that huge budgets are passed to buy ICT peripherals to improve teaching and learning but because of corruption only minor improvements are found in the technical and vocational education sector. Teachers' lack of knowledge and skills is one of the main barriers to use of ICT in the education sector (Mamun \& Tapan, 2009; Pelgrum, 2001; Ihmeideh, 2009; Williams, 1995). Furthermore, they also state that lack of knowledge of how to use ICT and lack of skills regarding ICT tools negatively affects the implementation of ICT in teaching and learning in Bangladesh. Furthermore, several factors found by researchers that directly and indirectly affect the implementation of ICT in education in Bangladesh include poor administrative support (Keengwe et al. 2008), the poor quality of training for teachers (Copley \& Ziviani, 2004; Mamun \& Tapan, 2009; Afshari et al. 2009) and lack of highly qualified ICT coordinators who can assist teachers to integrate ICT into the classroom, laboratory, and school culture (Afshari et al, 2009; Lim, 2002; Tearle, 2003).

\section{METHODOLOGY}

The strategy for identifying the main factors that affect teachers and the successful adoption and implementation of ICT in teaching and learning was a systematic literature review based on the following steps: formulate the review questions, define the selection criteria, and define the quality appraisal criteria (Croucher et al., 2003).

\section{The Review Question}

The review question provides focus and boundaries, and shapes all aspects of the review process, including: inclusion and exclusion criteria, search strategy, extent of the literature reviewed, quality appraisal, and the synthesis of the evidence (Wallace et al. 2005: 8). The review question was: What are the factors that affect teachers and the successful adoption and implementation of ICT in teaching and learning? 


\section{The Search Strategy}

Google, Google Scholar and Durban University of Technology library electronic databases were searched utilising search terms such as: "enhancing ICT adoption teaching and learning" and "enhancing ICT implementation for teachers".

\section{Application Of Study Selection Criteria}

Before studies entered into systematic review, they were subjected to two filters (Wallace et al. 2005). The first filter comprised a set of inclusion and exclusion criteria such that only literature that was relevant and able to address the review question was taken through the second filter (Wallace et al. 2005).

\section{Design Of The Studies}

Studies included in this review were those with empirical evidence from experimental or observational research, including qualitative research. The study included unpublished and published work (Wallace et al. 2005). In this literature review, only literature directly associated with the factors affecting teachers and the successful adoption and implementation of ICT in teaching and learning was selected.

\section{The Quality Appraisal Criteria}

Studies included in the literature review met all the five necessary elements of quality appraisal criteria (Wallace et al. 2005, source: Croucher et al. 2003) for valid and trustworthy findings. Articles were selected which were considerable, acceptable, reliable, and empirically valid. Included studies all had a good research question and theory or theoretical framework.

The next section (results) have developed from the existing literature and presented in Figure 1. 


\section{RESULTS}

The results of this study are displayed in Figure 1.

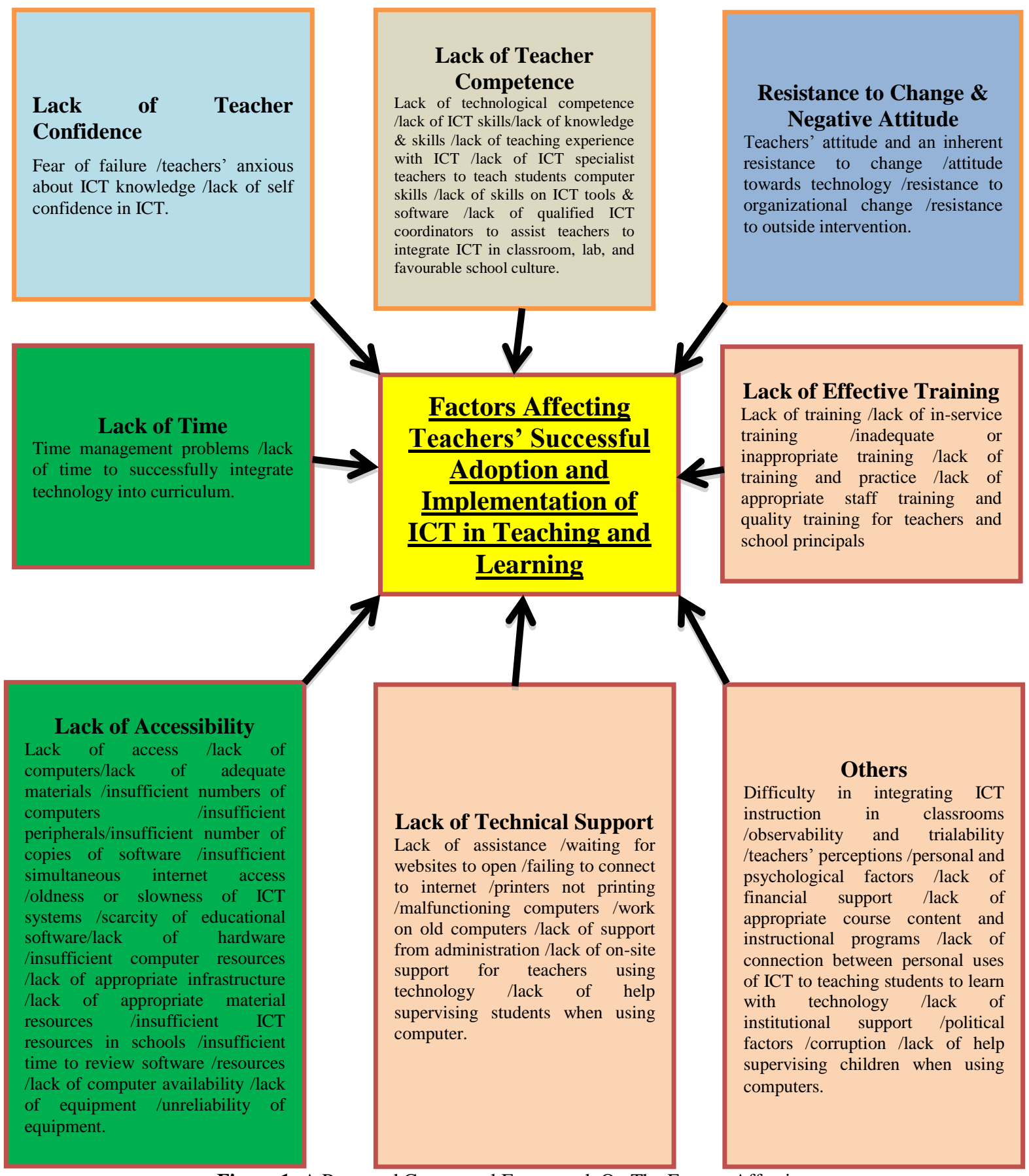

Figure 1: A Proposed Conceptual Framework On The Factors Affecting

To The Successful Adoption And Implementation Of ICT Into Teaching And Learning For Teachers 


\section{DISSCUSION, CONCLUSION AND RECOMMENDATION}

The main objective of the study was to examine the factors affecting teachers and the successful adoption and implementation of ICT in teaching and learning. This study has revealed all the major factors that affect school teachers. If the Technology Acceptance Model (TAM) is used then the following characteristics are referred to as negatively affecting the successful adoption and implementation factors: perceived usefulness, perceived ease of use, and user acceptance (Davis, 1989). Regardless of what theory is used, many factors including lack of teachers' confidence, lack of teachers' competence, resistance to change and negative attitudes, lack of time, lack of effective training, lack of accessibility, lack of technical support, difficulty in integrating ICT instruction in classrooms, observability and trialability are factors that inhibit school teachers' adoption and implementation of ICT in teaching and learning.

\section{AUTHOR INFORMATION}

Dr Sujit Kumar Basak is a lecturer in the Department of Information Technology, Durban University of Technology, Durban, KwaZulu-Natal, South Africa. His research interests are algorithms, IT education, and health informatics. E-mail: sujitbasakmca@gmail.com

Desmond Wesley Govender is a senior lecturer in the Department of Computer Science Education, University of KwaZulu-Natal, South Africa. He is currently the Discipline Leader of Computer Science Education and his research interests are technology integration in teaching and learning, programming paradigms, use of learning management systems to support learning. E-mail: govenderd50@ukzn.ac.za

\section{REFERENCES}

Al-Alwani, A. (2005). Barriers to integrating information technology in Saudi Arabia science education. Doctoral Dissertation, the University of Kansas, Kansas.

Afshari, M., Bakar, K. A., Su Luan, W., Samah, B. A., \& Fooi, F. S. (2009). Factors affecting teachers' use of information and communication technology. International Journal of Instruction, 2(1), 77-104.

Apawu, J. (2011). The use of memtd as ICT tools in the mathematics classroom in colleges of education in Ghana. European Journal of Social Science, 20(1), 90-99.

Aryatuha, H. (2007). Relationship between computerization and organizational effectiveness in day today running of business at MOH headquarters in Kampala. Unpublished Masters Dissertation, Makerere University, Kampala, Uganda.

Balanskat, A., Blamire, R., \& Kafal, S. (2007). A review of studies of ICT impact on schools in Europe- European schoolnet.

Beggs, T. A. (2000). Influences and barriers to the adoption of instructional technology. Proceedings of fifth annual mid-south instructional technology, Middle tennessee State University, USA.

Bisht, D. (2013). Integration of ICT in teacher education for enhancing competency based teaching. Techno Learn: An International Journal of Educational Technology, 3(1), 1-10.

British Educational Communications and Technology Agency (Becta). (2004). A review of the research literature on barriers to the uptake of ICT by teachers.

Brush, T., Glazewski, K., Rutowski, K., Berg, K., Stromfors, C., Van-Nest, M. H., Stock, L., \& Sutton, J. (2003). Integrating technology in a field-based teacher training program: the PT3@ASU project. Education Technology and Research Development, 51(1), 57-72.

Bullock, D. (2004). Moving from theory to practice: an examination of the factors that preservice teachers encounter as they attempt to gain experience teaching with technology during field placement experiences. Journal of Technology and Teacher Education, 12(2), 211-237.

Copley, J., \& Ziviani, J. (2004). Barriers to the use of assistive technology for children with multiple disabilities. Occupational Therapy International, 11(4), 229-243.

Cox, M., Preston, C., \& Cox, K. (1999). What factors support or prevent teachers from using ICT in their classrooms? Paper presented at the British educational research association annual conference.

Croucher, K., Quilgars, D., Wallace, A., Baldwin, S., \& Mather, L. (2003). Paying the Portage. A Systematic Literature Review of Safety Nets for Home Owners, York: Departments of Social Policy and Social Work. 
Davis, F. (1989). Perceived usefulness, perceived ease of use, and use acceptance of information technology. MIS Quarterly, 13(3), 319-40.

De Corte, E., Verschaffel, L., Entwistle, N., \& van Merrienboer, J. (Eds.). (2003). Powerful learning environments: unravelling basic components and dimensions, Oxford: Pergamon/Elsevier.

Dupagne, M., \& Krendl, K. A. (1992). Teachers' attitudes towards computers: a review of the literature. Journal of Research on Computing in Education, 24, 420-429.

Empirica (2006). Benchmarking access and use of ICT in European schools 2006: Final report from head teacher and classroom teacher surveys in 27 European countries. Germany: European commission.

Gomes, C. (2005). Integration of ICT in science teaching: a study performed in Azores, Portugal. Recent research developments in learning technologies.

Hadley, M., \& Sheingold, K. (1993). Commonalities and distinctive patterns in teachers' integration of computers. American Journal of Education, 101, 261-315.

Hsin-Kai, W., Ying-Shao, H., \& Fu-Kwun, H. (2007). Factors affecting teachers' adoption of technology in classrooms: does school size matter? International Journal of Science and Mathematics Education, 6, 6385.

Ihmeideh, F. M. (2009). Barriers to the use of technology in Jordanian pre-school settings. Technology, Pedagogy and Education, 18(3), 325-341.

Januszewski, A., \& Molenda, M. (Eds.). (2008). Educational technology: a definition with commentary, New York: Lawrence Erlbaum Associates.

Keengwe, J., \& Onchwari, G. (2008). Computer technology integration and student learning: barriers and promise. Journal of Science Education and Technology, 17(6), 560-565.

Kessy, D., Kaemba, M., \& Gachoka, M. (2006). The reasons for under use of ICT in education: in the context of Kenya, Tanzania and Zambia. Paper presented at the $4^{\text {th }}$ IEEE International Workshop on Technology for Education in Developing Countries, Iringa, Tanzania.

Korte, W. B., \& Hüsing, T. (2007). Benchmarking access and use of ICT in European schools 2006: Results from head teacher and a classroom teacher surveys in 27 European countries. E-learning papers, 2(10), 1-6.

Lim, C. P. (2002). A theoretical framework for the study of ICT in schools: a proposal. British Journal of Educational Technology, 4, 411-421.

Lim, Y. K. G., \& Teo, S. H. (1998). Effects of individual characteristics on police officers' work-related attitudes. Journal of Managerial Psychology, 13, 334-442.

Malcolm, E., \& Godwyll, F. (2008). Diffusion of information communication technology in selected Ghanaian Schools. Unpublished doctoral dissertation, Ohio University, USA.

Mamun, A., \& Tapan, S. M. (2009). Using ICT in teaching-learning at the polytechnic institutes of Bangladesh: constraints and limitations. Teacher's World-Journal of Education and Research, 33-34, 207-217.

Martins, C. B. M. J., Steil, A. V., \& Todesco, J. L. (2004). Factors influencing the adoption of the Internet as a teaching tool at foreign language schools. Computers and Education, 42, 353-373.

Mehlinger, H. D., \& Powers, S. M. (2002). Technology and teacher education: a guide for policy makers. Boston: Houghton Mifflin Company.

Mereku, D. K., Yidana, I., Hordzi, W., Tete-Mensah, I., Tete-Mensah, W., \& Williams, J. B. (2009). Ghana report. University of education, Winneba, Ghana.

Mumtaz, S. (2000). Factors affecting teachers' use of information and communication technology: a review of the literature. Journal of Information Technology for Teacher Education, 9(3), 319-341.

Natz, K., \& Lundgren, T. D. (1998). Lecturing with technology. College teaching, 46, 53-56.

Newhouse, P. (1999). Examining how teachers adjust to the availability of portable computers. Australian Journal of Educational Technology, 15(2), 148-166.

Nyambane, C. O., Nzuki, D. (2014). Factors influencing ICT integration in teaching- a literature review. International Journal of Education and Research, 2(3), 1-17.

Özden, M. (2007). Problems with science and technology education in Turkey. Eurasia Journal of Mathematics, Science \& Technology Education, 3(2), 157-161.

Pelgrum, W. J. (2001). Obstacles to the integration of ICT in education: results from a worldwide educational assessment. Computers \& Education, 37, 163-178.

Priscilla, M., Nida, M., Khambari, M., \& Wong, S. L. (2008). Factors that could possibly influence the use of Laptops among Educators. European Journal of Social Sciences, 7(1), 114. 
Pulkkinen, J. (2007). Cultural globalization and integration of ICT in education. In Kumpulainen, K. (Ed.). Educational Technology: Opportunities and Challenges, 13-23, Oulu, Finland: University of Oulu.

Republic of Uganda. (2007). National information and communication technology Policy. Kampala, Uganda.

Schoep, K. W. (2004). Technology integration barriers in a technology-rich environment: a CBAM perspective. Unpublished Master's Thesis, University of Calgary, Alberta.

Schrand, T. (2008). Tapping into active learning and multiple intelligences with interactive multimedia: a lowthreshold classroom approach. College Teaching, 56(2), 78-84.

Sharma, R. (2003). Barriers in using technology in developing countries, IEEE 0-7803-7724-9103.

Sherry, L., \& Gibson, D. (2002). The path to teacher leadership in educational technology. Contemporary Issues in Technology and Teacher Education, 2(2), 178-185.

Schoepp, K. (2005). Barriers to technology integration in a technology-rich environment. Learning and Teaching in Higher Education; Gulf Perspectives, 2(1), 1-24.

SchoolNetAfrica. (2004). Towards a strategy on developing African Teacher capabilities in the use of information and communication technology: Johannesburg: SchoolNet Africa.

Sicilia, C. (2005). The challenges and benefits to teachers' practices in constructivist learning environments supported by technology. Unpublished Master's Thesis, McGill University, Montreal.

Snoeyink, R., \& Ertmer, P. (2001). Thrust into technology: how veteran teachers respond. Journal of Educational Technology Systems (0047-2395), 30(1), 85.

Stockdill, S. H., \& Morehouse, D. L. (1992). Critical factors in the successful adoption of technology: a checklist based on TDC findings. Educational Technology, 1, 57-58.

Tearle, P. (2003). ICT implementation: what makes the difference? British Journal of Educational Technology, $34(5), 403-417$.

Tomei, L. A. (2005). Taxonomy for the technology domain. USA: Information Science Publishing.

Toprakci, E. (2006). Obstacles at integration of schools into information and communication technologies by taking into consideration the opinions of the teachers and principals of primary and secondary schools in Turkey. Journal of Instructional Science and Technology (e-JIST), 9(1), 1-16.

Volman, M., \& Van Eck, E. (2001). Gender equity and information technology in education: The second decade. Review of Educational Research, 71(4), 613-634.

Wallace, A., Bevan, M., Croucher, K., Jackson, K., O’Malley, L., \& Orton, V. (2005). The impact of empty, second and holiday homes on the sustainability of rural communities-a systematic literature review. The Centre for Housing Policy, The University of York, 1-142.

Webber, C. (2003). Introduction new technologies and educative leadership. Journal of Educational Administration, 41(2), 119-123.

Williams, B. (1995). Factors contributing to successful implementation of computer technology in schools. Dissertation Abstracts International, 56(8), 3092.

Williams, D., Wilson, K., Richardson, A., Tuson, J., \& Coles, L. (1998). Teachers' ICT skills and knowledge needs: report on a study conducted for Scottish office education and industry department. Aberdeen: The robert gordon University.

Winnans, C., \& Brown, D. S. (1992). Some factors affecting elementary teachers' use of the computer. Computers in Education, 18, 301-309.

Wood, D. (1995). Theory, training, and technology: Part I, Education and Training. 37(1), 12-16.

Wodi, S. W. (2008). The concept of educational technology: problems and prospects of information and communication technology (ICT) in Nigeria. International Journal of African Studies, 1, 4-10.

60. Zziwa, G. (2001). Computer utilization in the management of students' information at Makerere University. Unpublished Masters Dissertation, Makerere University, Kampala, Uganda. 